\title{
THE EFFECT OF ANAEROBIC AND AEROBIC EXERCISE ON ENDURANCE AND NON ENDURANCE ATHLETES ON PREMENSTRUAL SYNDROME (PMS)
}

\author{
(Experimental Study On Pengprov. Athletes Kota Padang)
}

\author{
Umar $^{1}$ \\ ${ }^{1}$ Fakultas Ilmu Keolahragaan, Universitas Negeri Padang \\ Padang - West Sumatra - Indonesia \\ E-mail: umarmardesia@gmail.com
}

\begin{abstract}
Premenstrual syndrome (PMS) is a symptom of discomfort that could happen 7-10 days before menstruation. This symptoms can be affect physiologically and psychologically. The purpose of this research is to investigate the influence of anaerobic and aerobic exercise in endurance and non endurance female athletes in related to the symptoms of premenstrual syndrome (PMS) either athletes and non athletes. The population consisted of all female athletes from various sports clubs in Padang as many 140 person, purposive sampling technique was used to take 70 female athletes who have premenstrual syndrome. Questionnaires and interviews is used to collect the data and t-test is used to analysis data on the level of significance $\alpha=0.05$. The result of this research are; there is no difference effect between aerobic and anaerobic exercise in non endurance athletes with PMS $(\rho=0.242>\alpha$ $0.05)$; there is difference effect between aerobic and anaerobic exercise on endurance athletes with PMS $(\rho=0.00<\alpha 0.05)$. It can be concluded that the aerobic exercise can reduce the symptoms of PMS better than anaerobic exercise.
\end{abstract}

\section{Introduction}

Intense competition between regions in every sport events to achieve the highest sport performance and prestige, requires the readiness of all relevant parties including the athletes, because the athlete is the main subject in every effort into highest sport performance. However, an athlete will not be able to do much without a well preparation, at least four main components to reach highest sport performance, namely; technical ability, physical, tactical / strategy and mental. All four components can be improved through the appropriate training process by professional trainers on the respective fields. However, often the process of training and participation of athletes in a game can not run optimally, this particularly occurs for female athletes who are biologically experiencing menstrual period every month. Generally, every woman will experience what is called Premenstrual Syndrome (PMS), the symptoms of feeling uncomfortable at the time of 7-10 days before menstruation. It is as quoted from Shin; Premenstrual Syndrome (PMS), is an unpleasant symptoms that are felt by a person 10-7 days before menstruation. PMS, which Affects Millions of women, has been recognized as a big nuisance. ${ }^{[8]}$ This is because 40 million women in the world suffer from the symptoms of this syndrome, and more than 5 million of them are going to medical treatment for mental and behavioral changes caused by this syndrome. ${ }^{[4]}$

These symptoms can affect physiologically (physical) such as; abdominal bloating, breast swelling and tenderness, fatigue, pelvic pain, back and muscle pain, and headaches. On the 
other hand, psychological symptoms will come to; irritability, emotional, crying easily, trouble in concentrating, forgetfulness and depression. It is as quoted from Stoppler (2014); "Premenstrual syndrome (PMS) is a combination of emotional, physical, psychological, and mood disturbances that occur after a woman's ovulation and typically ending with the onset of her menstrual flow". ${ }^{[1]}$ More from Stoppler (2014); "The most common mood-related symptoms are irritability, depression, crying, oversensitivity, and mood swings alternating with sadness and anger. The most common physical symptoms are fatigue, bloating, breast tenderness (mastalgia), acne, and appetite changes with food cravings ". [11]

Generally, increasing in emotional state at the time of premenstrual is influenced by hormones in the brain, especially the production of serotonin hormone or hormones that control emotional stability and followed by emotional turmoil as part of PMS (premenstrual syndrome) and begins to be felt at 7-10 days before menstruation. According to doctercomunity.blogspot.com. that; Excess serotonin can cause anxiety, confusion, increased heart rate, dilated pupils, loss of muscle coordination, sweating, diarrhea, headache, chills, nausea, vomiting, convulsions, high fever, irregular heartbeat, uncontrolled movement, and loss of consciousness. Serotonin deficiency can cause anxiety, depression, phobias, pessimistic, anxious, insecure, irritability, sleep disorders, PMS, headaches and backaches. ${ }^{[6]}$

This condition will certainly affect the performance of female athletes in training or in competition. Thus, the main problem in this research is that there are still a lot of female athletes who experience the uncomfortable symptoms as a result of premenstrual syndrome, who can disrupt (decrease) their performance during exercises or in competition, up until now there is no agreement between the scientist which form of exercise can reduce the symptoms of premenstrual syndrome.

There are several factors that can affect the premenstrual syndrome (PMS) include; hormonal disorders (imbalance of estrogen and progesterone hormones), the presence of genetic variations in the sensitivity of the receptor, the interaction of serotonin stability, physical activity, nutritional status, health status, physical fitness level. It is as it was concluded from the results of research Serena (2007), Johnson (2007) and Ugarizze (1998) that; Increased renin-angiotensin activity and decreased levels of estrogen and progesterone as factors in increased serum levels of aldosterone in the late luteal phase are listed. ${ }^{[8]}$

As stated previously, this study is to investigate the influence of the physical exercise (anaerobic and aerobic exercise) toward the Premenstrual Syndrome (PMS), because theoretically it is said that by doing various physical activities (including training) will reduce premenstrual syndrome disorders, this is due to the increase of the hormone endorphin hormone which gives a sense of comfort, and on the other hand suppresses the production of prostaglandin hormone which is a hormone that causes pain. In addition, physical exercise can control the production of serotonin which is a trigger for symptoms of Premenstrual Syndrome (PMS). However, it is not yet reaffirmed which form of physical activity can reduce the symptoms of PMS. Hopefully the results of this research can be used as a reference for the various parties concerned, especially for athletes and coaches as well as larger communities in order to reduce PMS symptoms.

\section{Methodology}

Ex post facto is designed to conduct in this research. 140 female athletes as research population, which is prepared to take participation in PORWIL and Kejurnas / Pre-PON in provincial training camp (Pelatprov.) of West Sumatra. 40 samples was restricted to the endurance female athletes and 30 samples non endurance female athletes who experience 
premenstrual syndrome. The instruments used to collect the data are interviews and questionnaires. While the research steps for information gathering; Observations and interviews to the provincial board / health club, distributing questionnaires to the athletes to obtain data about premenstrual syndrome, inventorying the of training provided by the coach to athletes, and reviewing the literature. Data analysis using descriptive statistics and inferential statistics by $\mathrm{t}$ test at significance level $\alpha$ 0:05.

\section{Results}

According to the first hypothesis; There is no difference effect between the of anaerobic exercise and aerobic exercise in non-endurance athletes to premenstrual syndrome, whose $\rho$ $=0.242>\alpha 0.05$. as can be seen in the table below;

Table 1

The data analysis results of non-endurance athletes group

\begin{tabular}{|c|c|c|c|c|c|c|c|c|c|}
\hline & & \multicolumn{5}{|c|}{ Paired Differences } & \multirow[t]{3}{*}{$t$} & \multirow[t]{3}{*}{ Df } & \multirow{3}{*}{$\begin{array}{l}\text { Sig. } \\
(2- \\
\text { tailed })\end{array}$} \\
\hline & & \multirow[t]{2}{*}{ Mean } & \multirow[t]{2}{*}{$\begin{array}{c}\text { Std. } \\
\text { Deviation }\end{array}$} & \multirow[t]{2}{*}{$\begin{array}{l}\text { Std. Error } \\
\text { Mean }\end{array}$} & \multicolumn{2}{|c|}{$\begin{array}{l}95 \% \text { Confidence } \\
\text { Interval of the } \\
\text { Difference } \\
\end{array}$} & & & \\
\hline & & & & & Lower & Upper & & & \\
\hline $\begin{array}{l}\text { Pair } \\
1\end{array}$ & $\begin{array}{l}\text { Anaerobic and Aerobic } \\
\text { Exercise Non } \\
\text { Endurance Athletes }\end{array}$ & .875 & 4.659 & .737 & -.615 & 2.365 & 1.188 & 39 & .242 \\
\hline
\end{tabular}

On the other; There is differenceteffect between the of anaerobic exercise and aerobic exercise in endurance female athletes to premenstrual syndrome, whose $\rho=0.00<\alpha 0.05$. It can be concluded that the aerobic exercise give more positive effects on reducing the symptoms of premenstrual syndrome, both physiological and psychological symptoms. In general aerobic exercise can reduce the symptoms of premenstrual syndrome better than anaerobic exercise, especially to endurance female athletes. For more details can be seen in the following table;

\section{Table 2}

The data analysis results of endurance athletes group

Paired Samples Test

\begin{tabular}{|c|c|c|c|c|c|c|c|c|c|}
\hline & & \multicolumn{5}{|c|}{ Paired Differences } & \multirow[t]{3}{*}{$\mathrm{t}$} & \multirow[t]{3}{*}{ Df } & \multirow{3}{*}{$\begin{array}{l}\text { Sig. } \\
(2- \\
\text { tailed })\end{array}$} \\
\hline & & \multirow[t]{2}{*}{ Mean } & \multirow[t]{2}{*}{$\begin{array}{c}\text { Std. } \\
\text { Deviation }\end{array}$} & \multirow[t]{2}{*}{$\begin{array}{l}\text { Std. } \\
\text { Error } \\
\text { Mean }\end{array}$} & \multicolumn{2}{|c|}{$\begin{array}{c}95 \% \text { Confidence } \\
\text { Interval of the } \\
\text { Difference }\end{array}$} & & & \\
\hline & & & & & Lower & Upper & & & \\
\hline $\begin{array}{l}\text { Pair } \\
1\end{array}$ & $\begin{array}{l}\text { Anaerobic and } \\
\text { Aerobic Exercise } \\
\text { Endurance Athletes }\end{array}$ & 103.900 & 4.722 & .862 & -105.663 & $102.137^{-}$ & -120.510 & 29 & .000 \\
\hline
\end{tabular}




\section{Discussion}

Based on the analysis of data, it turns out the first hypothesis is rejected. The first hypothesis was declined due to the possibility that the non-endurance female athletes were more dominant on doing the of anaerobic exercise. Anaerobic exercises focus on speed, power and explosive power, so that the time spent in training (excitatory time) relatively quick and not enough time for aerobic metabolism.

Meanwhile, the results of data analysis proved that the second hypothesis can be accepted as true. This is caused by doing aerobic exercises, especially in endurance female athletes will increase the endorphin hormones and lower the levels of the prostaglandin hormone, this is related to what Santosa Griwijoyo said, that; Reduction in PMS symptoms as a result of physical activity is likely due to changes by the influence of exercise on the central neurotransmitter eg, $\beta$-endorphin and or reduction in prostaglandin, which is a mediator associated with pain in the uterus. ${ }^{[7]}$

It is as it was concluded from the results of research Serena (2007) that; Increased reninangiotensin activity and decreased levels of estrogen and progesterone as factors in increased serum levels of aldosterone in the late luteal phase are listed, ${ }^{[8]}$

The same thing with what is said by Santosa above, Rizqi Adnamazida from She Knows states that: "One of the best ways to cope with PMS (pre-menstrual syndrome) is to exercise, and one kind of exercise recommended is aerobic exercise". ${ }^{[2]}$

On the other hand Berawi said that; almost all women experience discomfort in the lower abdomen during menstruation, however, it is very easy to cure through a light but regular exercise such as aerobics gymnastics which be done before and during menstruation can make blood stream in the muscles around the uterus flows smoothly, so that the menstrual pain can be resolved. ${ }^{[4]}$

In a study by Steege in 1993 on the effect of aerobic in comparison to strength exercise in 23 women having PMS increased aerobic compliance and decreased depression were shown to be more significant in aerobic exercise, though par-ticipation in both types of exercise resulted in a decrease in many PMS symptoms. ${ }^{[12]}$

The repetitive contraction in the aerobic exercise helps venous blood to return, resulting in the increase of prostaglandins and other substances which help prevent and reduce back pain and discomfort in the pelvis and the abdomen. ${ }^{[1]}$

It is as said by Aganoff (1994) believed that aerobic activity through an increase in brain endorphin and reduction of adrenal cortisol results in the improvement of PMS symptoms and psychological symptoms that may occur due to reduced beta-endorphins. ${ }^{[2]}$

Furthermore, according to Berawi, that; Aerobics gymnastis exercise is believed can minimize the complaints of menstrual pains in some ways, due to suppress the production of prostaglandins, responding and adapting to hormone regulation. Moreover, it makes the body produce endorphins, a chemical reaction that serves as a natural pain reliever on the pelvis, the achievement of estrone-estradiol ratio that can reduce endometrial proliferation, and improve blood circulation in the uterus.

Aerobic gymnastics exercise is counted as endurance sport, because for every session of exercise should be done at least 15 minutes with the accompaniment of music, 


\section{Conclusion}

Based on the analysis, it can be concluded that; anaerobic exercises, there is no significant effect on the reduction of the premenstrual syndrome symptoms, in both to the endurance and non-endurance female athletes. While of aerobic exercise can reduce the symptoms of premenstrual syndrome, especially for endurance female athletes.

\section{References;}

1. Abbaspour Z, Rostami M, Najjar SH. (2006). The effect of exercise on primary dysmenorrhea. J Res Health Sci. ;6:26-31.

2. Adnamazida, R. http://www.merdeka.com/sehat/7-olahraga-yang-cocok-dilaku-kan-saatdatang-bulan.html, 2012 18:20:22.

3. Aganoff JA, Boyle GJ. (1994). Aerobic exercise, mood states and menstrual cycle symptoms. J Psychosom Res. ;38:183-92.

4. Berawi K. Nisa. http://www.radarlampung.co.id/read/bdarlampung/metropolis/ 32981aerobik-redakan-nyeri-haid,

5. Daley A. (2009). Exercise and premenstrual symptomatology: A comprehensive review. J Womens Health (Larchmt) ;18:895-9.

6. http://doctercomunity.blogspot.com/2011/01/hormon-progesteron.html.

7. Santosa Griwijoyo, Didik Zafar Sidik, Ilmu Kesehatan Olahraga (Bandung: PT Remaja Rosda Karya Offset, 2012), h. 186.

8. Serena S, Khaled M. (2007). Premenstrual syndrome. J Obstet Gynecol Reprod Med. ;18:226-35.

9. Shin KR, Ha JY, Park HJ, Heitkemper M. (2009). The effect of hand acupuncture therapy hand moxibustion therapy on premenstrual-syndrome among korean women. West $\mathbf{J}$ Nurs Res. 2009;31:171-86.Available from: http://www. sagepub.com//.; http://www.usdoctor.com/2011.

10. Steege JF, Blumenthal JA. (1993). The effects of aerobic exercise on premenstrual symptoms in middle-aged women: a preliminary study. J. Psychosom Res. 1993; 37:127-33.

11. Stoppler, M. C. (2014). Premenstrual Syndrome (PMS). http://www.medicinenet.com/premenstrual_syndrome/article.htm

12. Zinat Ghanbari, M.D. (2008), The effect of Three Months Regular Aerobic Exercise on Premenstrual Syndrome. Journal of Family and Reproductive Health. Vol. 2, No. 4, December 2008 